\title{
Autoryzacja w praktyce nowych mediów w dobie kryzysu systemu prawa prasowego
}

J eżeli przyjmiemy, iż kryzys to [...] przesilenie, moment rozstrzygajacy, okres przełomu, załamanie się dotychczasowej linii rozwoju [...], sytuacja w której następuje upadek dotychczasowych wartości, a nie wyksztatcaja się jeszcze nowe, które mogtyby zajać ich miejsce ${ }^{1}$, to można zastanawiać się, czy nie obserwujemy kryzysu prawa prasowego w Polsce? Zważywszy na siłę, zakres krytyki obowiązującej ustawy z dnia 26 stycznia 1984 r. Prawo prasowe ${ }^{2}$, jak i wielokrotne próby zmiany istniejącego stanu prawnego, być może można wręcz mówić o permanentnym stanie kryzysowym. Po pierwsze atakuje się obowiązującą ustawę z uwagi na jej genezę (uchwalenie w styczniu 1984 r.) i nadal istniejące ,pozostałości” PRL-u w jej treści ${ }^{3}$. Po drugie od dłuższego czasu pojawiają się wręcz głosy, iż prawo prasowe w ogóle nie jest potrzebne (i to nie tylko dziennikarzom $)^{4}$. Wreszcie po trzecie, powodem krytyki jest ,nieprzystosowanie" regulacji powstałej w erze analogowych mediów, do nowej rzeczywistości medialnej wynikającej z cyfryzacji.

Z pewnością autoryzacja jest jedną z instytucji, która wzbudza wiele krytyki z każdego praktycznie wyżej zaprezentowanego powodu. Nie jest ona znana regulacjom OBWE, Rady Europy $^{5}$ ani Unii Europejskiej, choć występuje w niektórych krajowych porządkach prawnych państw europejskich ${ }^{6}$.

${ }^{1}$ Hasło „kryzys” w: Nowa encyklopedia powszechna PWN, red. B. Petrozolin-Skowrońska, t. 3, s. 586.

${ }^{2}$ Dz. U. Nr 5, poz. 24 z późn. zm.

${ }^{3}$ Owe relikty PRL-u w prawie prasowym są oczywiście kosmetyczne, mają wymiar jedynie semantyczny, ale z pewnością nie przynoszą chluby ustawodawcy. Jako przykłady należy wskazać: art. 2 Organy państwowe zgodnie z Konstytucja Polskiej Rzeczypospolitej Ludowej [...]; Art. 9. Przepisów niniejszej ustawy nie stosuje się do: 1) Dziennika Ustaw Polskiej Rzeczypospolitej Ludowej, Dziennika Urzędowego Polskiej Rzeczypospolitej Ludowej „Monitor Polski" oraz innych urzędowych organów publikacyjnych, 2) Diariusza Sejmowego i własnych sprawozdań z działalności Sejmu i jego organów, a także wewnętrznych wydawnictw rad narodowych, art. 25 ust. 3 Redaktorem naczelnym dziennika lub czasopisma nie może być osoba skazana za zbrodnie przeciwko podstawowym interesom politycznym i gospodarczym Polskiej Rzeczypospolitej Ludowej. Warto tu wskazać, że owe „pozostałości po PRL” zamierza usunąć projekt nowelizacji prawa prasowego z 23 maja 2012 r., zob. druk sejmowy nr 459. Ponadto można się także zastanawiać nad sensem utrzymywania w ustawie rozdziału 3 poświęconego Radzie Prasowej, która w praktyce od wielu lat nie istnieje. Trzeba tu dodać, że rady prasowe mają długą tradycję w wielu krajach. Patrz szerzej na ten temat L. Fielden, Regulating the Press. A Comparative Study of International Press Councils, Raport, Oxford April 2012, tekst dostępny na stronie eutersinstitute.politics.ox.ac.uk/fileadmin/documents/Publications/Working_Papers/Regulating_the_Press.pdf (data wejścia 30.12.2012).

${ }^{4}$ S. Bratkowski, Dlaczego nie potrzeba prawa prasowego?, wykład wygłoszony 27.10.2009 r., tekst dostępny na stronie http://www.hfhrpol.waw.pl/obserwatorium/images/konferencje/prawo\%20prasowe/Bratkowski\%20-\%20Pr_prasowe.PDF.

${ }^{5}$ Tym niemniej w doktrynie pojawiały się wątpliwości, co do jej zgodności z art. 10 Europejskiej Konwencji Praw Człowieka. Tak I. C. Kamiński, Autoryzacja wypowiedzi a europejskie standardy swobody wypowiedzi, w: Autoryzacja wypowiedzi w prawie prasowym - wyrok TK i co dalej?, red. A. Bodnar, D. Bychawska-Siniarska, Warszawa 2008, s. $19-24$.

${ }^{6}$ Stan prawny we Francji, Niemczech, Wielkiej Brytanii opisuje J. Taczkowska, Autoryzacja, s. 14-45; zob. także J. Sobczak, Prawo prasowe. Komentarz, Warszawa 2008, s. 546-555; E. Nowińska, op. cit., s. 114-117. 
Przypomnijmy, że zgodnie z obecnym art. 14 ust. 2 pr.pr. dziennikarz nie może odmówić osobie udzielającej informacji autoryzacji dosłownie cytowanej wypowiedzi, o ile nie była ona uprzednio publikowana ${ }^{7}$. Jak z powyższego wynika, podstawową funkcją tej instytucji jest zagwarantowanie autorowi wypowiedzi udzielanej przedstawicielom prasy, ochrony treści własnej wypowiedzi i zapewnienia jej integralności i właściwej - zgodnej z intencją autora - wymowy ${ }^{8}$. W doktrynie wskazuje się, że na tę instytucję składa się wiele uprawnień dla osoby uprawnionej ${ }^{9}$, takich jak: możliwość oznaczenia wypowiedzi własnym nazwiskiem, wglądu w treść wypowiedzi przed jej publikacją, korygowania jej kształtu, wyboru adresatów wypowiedzi, okoliczności jej przekazania oraz wyboru formy wypowiedzi, a także prawo zezwalania na jej rozpowszechnienie ${ }^{10}$. Należy też tu wyjaśnić, że termin ,wypowiedź” w tym przepisie należy tu rozumieć jako wypowiedź słowna, utrwalonq obojętnym sposobem, w tym i na taśmie filmowej. Autoryzowana jest więc nie jej forma, lecz treść $[. . .]^{11}$. Należy zatem przyjąć, że chodzi o wypowiedź w wąskim znaczeniu, a nie samą prezentację wizualną lub dźwiękową jednak bez słów ${ }^{12}$.

Autoryzacja wzbudzała wiele kontrowersji, przede wszystkim z powodu zastrzeżeń natury ustrojowej i zarzutu ograniczania wolności słowa ${ }^{13}$. Krytycy tej instytucji twierdza, iż z niej wynikaja dla informatora dwa podstawowe uprawnienia: po pierwsze, prawo do zapoznania się z własna wypowiedziq, w takiej formie, w jakiej ma ona zostać zacytowana $w$ materiale prasowym; po drugie, nieograniczone w żaden sposób prawo do zablokowania publikacji tej wypowiedzi. Celem rozpatrywanej konstrukcji jest więc nie tyle zagwarantowanie rzetelności cytowania przez prase, co przyznanie osobom udzielajacym jej informacji prawa do reflek $s j i^{14}$. Stąd też w doktrynie, ale zwłaszcza wśród przedstawicieli praktyki zawodu ${ }^{15}$, formułowano często zarzuty o niezgodności przepisu autoryzacyjnego z Konstytucją ${ }^{16}$. Wątpli-

\footnotetext{
${ }^{7}$ Dodać tu trzeba, że w art. 49 pr.pr. penalizuje się naruszenie obowiązku autoryzacji, przewidując karę grzywny lub ograniczenia wolności. Przepis ten był przedmiotem analizy Trybunału Konstytucyjnego, który uznał zgodność przepisu z art. 54 ust. 1 w zw. z art. 31 ust. 3 Konstytucji RP. Zob. Wyrok T.K. z dnia 29 września 2008 r. teza 1 (sygn. akt SK 52/05, opublik. w Dz. U. 2008, Nr 178, poz. 1103; „OTK-A” 2008, nr 7, poz. 125, a także A. Bodnar, D. Bychawska-Siniarska (red.), op. cit., s. 81-93).

${ }^{8}$ J. Sobczak, Prawo prasowe, s. 539-540.

${ }^{9}$ W judykaturze wskazywano na dwa główne uprawnienia, a mianowicie możliwość zapoznania się z wypowiedzią w takiej formie, w jakiej ma być cytowana w materiale prasowym oraz możliwość zakazania publikacji takiej wypowiedzi. Zob. wyrok Sądu Okręgowego w Poznaniu z 6 października 2004 r. IV Ka 1523/03, niepublikowane, cyt. za M. Zaremba, Prawo prasowe. Ujęcie praktyczne, Warszawa 2007, s. 110-111.

${ }^{10}$ J. Sobczak, op. cit., s. 540.

${ }^{11}$ E. Nowińska, op. cit., s. 119.

12 J. Taczkowska, op. cit., s. 62.

${ }^{13}$ Patrz szerzej J. Taczkowska, Autoryzacja, s. 85-160; tej samej autorki, Konstruktywne i destruktywne funkcje autoryzacji, w: Kulturowe instrumentarium wolności. Etyka i Prawo, red. R. Paradowski, Poznań 2005, s. 275-285; J. Sobczak, Prawo prasowe, s. 539-565; A. Bodnar, Wstę, w: A. Bodnar, D. Bychawska-Siniarska (red.), op. cit., s. 5-9; W. Machała, Autoryzacja-ograniczenie czy gwarancja wolności słowa?, „Palestra” 2006, z. 7-8 s. 110-113.

${ }^{14}$ M. Zaremba, Prawo prasowe. Ujęcie praktyczne, Warszawa 2007, s. 110-111.

${ }^{15}$ Choć niektórzy dziennikarze zdecydowanie bronią tej instytucji. Zob. T. Torańska, Autoryzacja wypowiedzi w prawie prasowym: wyrok i co dalej?, w: A. Bodnar, D. Bychawska-Siniarska (red.), op. cit., s. 19-24. Natomiast J. Taczkowska zauważa, że krytyczne stanowisko wobec instytucji autoryzacji nie jest pogladem dominujacym w środowisku dziennikarzy. Jest jednak stanowiskiem nośnym, chwytliwym, które daje się latwo i przekonujaco uzasadniać. Krytycy autoryzacji porównuja jq często do cenzury prewencyjnej [...] Autoryzacja, w ścisłym jej rozumieniu ogranicza swobodę dziennikarskich zachowań, jednak ograniczenie to służy swobodzie wypowiedzi, a wonsekwencji także samej wolności prasy. J. Taczkowska, Autoryzacja, s. 159. Niemniej pojawiają się także takie określenia tej instytucji jak przekleństwo polskich dziennikarzy. M. Nowicki, Autoryzacja a wolność słowa, „Newsweek” 2001, nr 10, s. 94, cyt. za: J. Taczkowska, Konstruktywne, s. 277.

${ }^{16}$ M. Zaremba, O sprzeczności instytucji autoryzacji z Konstytucja, ,Palestra” 2006, z. 3-4, s. 56-71; idem, Prawo, s. 113-116. Dyskusję reprezentantów praktyki przedstawia J. Taczkowska, Autoryzacja, s. 146-157. Por. także
} 
wości te rozwiał Trybunał Konstytucyjny w wyroku z 29 września 2008 r. przesądzając, że art. 14 ust. 2 pr.pr. jest zgodny z art. 54 ust. 1 w zw. z art. 31 ust. 3 Konstytucji ${ }^{17}$. Warto przypomnieć, że w toku postępowaniu przed Trybunałem skarżący argumentował, iż art. 14 ust. 1 i 2 oraz art. 49 Prawa prasowego, stosowane łącznie, ograniczają wolność prasy oraz wolność słowa, przejawiające się w swobodzie rozpowszechniania informacji pod postacią zapisów wizualnych, w szczególności zdjęć ${ }^{18}$. Jak już wyżej wspomniano, ocena tej instytucji przez Trybunał Konstytucyjny, była jednak inna. Zdaniem Trybunału autoryzacja jest przejawem realizacji prawa obywateli do rzetelnej, czyli wiarygodnej, prawdziwej, uczciwej, jasnej, niewprowadzającej w błąd, odpowiedzialnej informacji i choć prawo to nie zostało dosłownie wyrażone w Konstytucji, ale ma w niej swoiste ,zakotwiczenie”. Wyjaśniono, że wprawdzie wartości zakorzenione $w$ Konstytucji nie maja cech systemu, sq jedynie zbiorem elementów, ale to nie znaczy, iż między wartościami (tymi elementami) nie zachodza relacje konieczności $i$ wynikania. Prawo prasowe nakładała na skarżacego, który byt redaktorem naczelnym, jednoznaczny obowiazek uzyskania autoryzacji wypowiedzi przez osobę udzielajaca wywiadu przed publikacja tego wywiadu, bez względu na jego przedmiot i jej treśśc ${ }^{19}$.

Co niezwykle interesujące, sprawa ta była także analizowana przez Europejski Trybunał

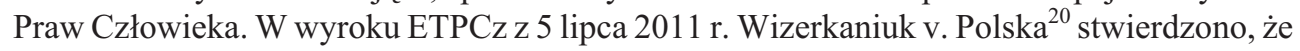
„,autoryzacja sprowadza się do zaświadczenia, iż tekst zaproponowany do publikacji odpowiada rzeczywistemu brzmieniu danych wypowiedzi. Skarżący przeprowadził wywiad z miejscowym posłem na Sejm dotyczący jego działalności politycznej i gospodarczej. Jego poglądy i komentarze bez wattpienia stanowiły kwestię publicznego zainteresowania dla społeczności lokalnej, skarżący był uprawniony do przedstawienia ich społeczeństwu, a lokalna społeczność była uprawniona do uzyskania informacji dotyczących takich kwestii. Po-

stanowiska Rzecznika Praw Obywatelskich, Prokuratora Generalnego, Marszałka Sejmu RP w tej sprawie, domagające się uznania kwestionowanych przepisów za niezgodne z Konstytucją. Patrz uzasadnienie Wyroku TK z 29.09.2008 r., w: A. Bodnar, D. Bychawska-Siniarska (red.), op. cit., s. 83-86.

17 Zob. tezę 2 tego wyroku. Takie stanowisko TK spotkało się z krytyką. Por. Zdanie odrębne sędziego Andrzeja Rzeplińskiego do wyroku TK o sygn. SK 52/05, w: A. Bodnar, D. Bychawska-Siniarska (red.), op. cit., s. 94-106. Patrz także M. Zaremba, Komentarz do wyroku Trybunału Konstytucyjnego w sprawie autoryzacji, w: A. Bodnar, D. Bychawska-Siniarska (red.), op. cit., s. 12-18; I. C. Kamiński, Autoryzacja, s. 19-24; B. Kordasiewicz, Autoryzacja wypowiedzi w prawie prasowym: wyrok TK $i$ co dalej?, w: A. Bodnar, D. Bychawska-Siniarska (red.), op. cit., s. 29-32. Skarga konstytucyjna została wniesiona w związku z następującym stanem faktycznym. Wyrokiem Sądu Okręgowego w Poznaniu z 6 października 2004 r. (sygn. akt IV Ka 1523/04), utrzymano w mocy wyrok Sądu Rejonowego w Poznaniu z 30 kwietnia 2004 r. (sygn. akt V K 458/04), w którym skarżący został uznany za winnego przestępstwa na podstawie art. 49 w związku z art. 14 ust. 1 i 2 Prawa prasowego, tj. naruszenia dóbr osobistych posła na Sejm, przez publikację wywiadu przeprowadzonego z nim 24 lutego 2004 r. i wykonanych wówczas zdjęć posła bez jego wyraźnej i jednoznacznej zgody. Postępowanie w sprawie przeciwko skarżącemu zostało warunkowo umorzone na rok, a skarżący został zobowiązany do zapłaty kwoty 1000 zł na wskazany przez_sąd cel społeczny.

${ }^{18}$ Skarżący podkreślił, że w odniesieniu do prasy i gwarantowanej wolności środków społecznego przekazu (art. 14 Konstytucji) ustrojodawca przewidział jej szczególną, uprzywilejowaną pozycję prawną. Tymczasem - zdaniem skarżącego - kwestionowane przepisy nie spełniają wymogu „konieczności” wprowadzenia tego typu regulacji w państwie demokratycznym zgodnie z art. 31 ust. 3 Konstytucji. Jak zauważono, przepis art. 14 ust. 1 w związku $\mathrm{z}$ art. 49 Prawa prasowego, umożliwia pociągnięcie do odpowiedzialności karnej dziennikarza, który rozpowszechnia cudzy wizerunek także w wypadku, gdy przedstawia on tzw. osoby publiczne, a więc przykładowo posła, a wizerunek ten wykonano w związku z prowadzeniem przez te osoby ich działalności publicznej.

${ }^{19}$ Patrz uzasadnienie Wyroku TK z 29.09.2008 r., w: A. Bodnar, D. Bychawska-Siniarska (red.), op. cit., s. 83-86.

${ }^{20}$ Tekst dostępny na stronie http://hudoc.echr.coe.int/sites/eng/Pages/search.aspx\#\{,,fulltext”:[,,case\%20\%2018990/05”],"documentcollectionid”:[,_COMMITTEE”,”DECISIONS”,"COMMUNICATEDCASES”, "CLIN","ADVISORYOPINIONS","REPORTS","RESOLUTIONS”],"itemid”:[,,001-105557”]\} (data wejścia 30.12.2012). 
nadto zaskarżone przepisy miały powszechne zastosowanie, bez względu na status osoby udzielającej wywiadu. Dla zastosowania sankcji karnej wystarczyło, by sąd wykazał, iż skarżący nie uzyskał autoryzacji. W ocenienie ETPCz w tej instytucji dostrzec można pewien paradoks, a mianowicie im wierniej dziennikarze przekazuja wypowiedzi osoby udzielajacej wywiadu, tym bardziej sq narażeni na ryzyko wszczęcia przeciwko nim postępowania karnego za brak autoryzacji. Podobnie paradoksalnym jest to, iż art. 14 pr.pr. zobowiazuje dziennikarzy do uzyskania autoryzacji jedynie w odniesieniu do wywiadów utrwalonych za pomoca zapisów fonicznych lub wizualnych, podczas gdy brak jest takiego obowiazku w przypadku sporzqdzania przez dziennikarza jedynie notatek podczas wywiadu. Należy w każdym razie uznać, iż sam fakt, iz skarżacy mógt sparafrazować słowa użyte przez osobę udzielajaca wywiadu - lecz zamiast tego zdecydowat się na publikacjejej dosłownych wypowiedzi i został za to ukarany - nie sprawia, by nałożona na niego sankcja karna stała się proporcjonalna. Należy uznać, iż postępowanie karne wszczęte przeciwko skarżacemu oraz sankcja karna na niego nałożona, przy braku jakiegokolwiek uwzględnienia dokładności oraz przedmiotu opublikowanego tekstu oraz pomimo niekwestionowanej staranności dołożonej przez skarżacego, by tekst opublikowanego wywiadu odpowiadat rzeczywistym wypowiedziom posła na Sejm, byty nieproporcjonalne $w$ tych okolicznościach ${ }^{21}$.

Analizując istotę tej instytucji w świetle obowiązującego stanu prawnego, stwierdza się, że jest to prawo podmiotowe ${ }^{22}$, które ma charakter osobisty ${ }^{23}$, co oznacza, że nikt oprócz osoby uprawnionej nie może dysponować tym uprawnieniem, choć oczywiście można działać poprzez pełnomocnika ${ }^{24}$. Uprawnienie takie przysługuje każdej osobie fizycznej, która udzieliła wypowiedzi. Nie ma znaczenia ich ewentualny status publiczny, tzn. czy są to osoby pełniące funkcje publiczne, czy też nie posiadają takiej pozycji, czy wypowiedź została udzielona w związku z pełnieniem takiej funkcji ${ }^{25}$. Natomiast nie będzie ona przysługiwać osobom prawnym. Jest to o tyle zrozumiałe, że w przypadku osób prawnych wypowiedzi udzielać będzie osoba fizyczna, która udziela wypowiedzi w imieniu osoby prawnej, jej organu lub inna osoba upoważniona (np. rzecznik prasowy).

W doktrynie pojawiają się spory dotyczące zastosowania tej instytucji w sytuacji relacjonowania przebiegu rozpraw sądowych. Pierwszą zasadniczą kwestią jest rozstrzygnięcie czy w takim przypadku autoryzacja będzie mogła mieć zastosowanie. Zdaniem niektórych przedstawicieli doktryny, taki obowiązek może powstać w przypadku cytowania wypowiedzi podczas rozprawy i wówczas takim uprawnieniem dysponować będzie sąd orzekający w sprawie, bez względu na okoliczność czy będzie to wypowiedź sądu, czy też któregokolwiek uczestni$\mathrm{ka} \mathrm{postępowania}^{26}$. Z takim poglądem jednak trudno się zgodzić. Po pierwsze trzeba przypomnieć, że kwestie utrwalania obrazu i dźwięku regulują odrębne przepisy proceduralne ${ }^{27}$. Po drugie podzielić należy pogląd, że zezwolenie sqdu na dokonywanie utrwaleń obrazu i dźwięku z przebiegu rozprawy nie zdejmuje z prasy odpowiedzialności za treść wyemitowanego obrazu. Uzyskanie zezwolenia na prowadzenie nagrania, na utrwalenie przebiegu rozprawy, nie

${ }^{21}$ W konkluzji stwierdzono naruszenie art. 10 Konwencji. Ibidem.

${ }^{22}$ Analizę czy jest to $\mathrm{w}$ istocie prawo podmiotowe zaprezentowano poniżej.

23 J. Sobczak, Prawo, op. cit., s. 559.

${ }^{24}$ Ibidem.

${ }^{25}$ M. Zaremba, op. cit., s. 111.

${ }^{26}$ B. Wójcicka, Jawność postępowania karnego w polskim procesie karnym, Łódź 1989. cyt. za M. Zaremba, op. cit., s. 111. Pogląd ten cytuje i podziela N. Gill, Dziennikarskie formy sprawozdawczości sq̨dowej, w: Wręu mediów i polityki, red. D. Piontek, Poznań 2003, s. 60.

27 J. Sobczak, Dziennikarz - sprawozdawca sqdowy. Prawa i obowiazki, Warszawa 2000, s. 176-180. 
jest jednoznaczne z zezwoleniem na opublikowanie audycji ${ }^{28}$. Tym niemniej wydaje się jednak, że w takich przypadkach art. 14 ust. 1 jak i ust. 2 tego przepisu pr.pr. nie będą miały zastosowania $^{29}$. Po trzecie trzeba pamiętać, iż w przypadku autoryzacji chodzi o sytuację udzielenia informacji przedstawicielom prasy, a nie o wszystkie sytuacje, gdy dziennikarz uzyskuje wypowiedź. Podczas rozprawy (bez względu na rodzaj procedury) to sąd jest podmiotem, który uzyskuje te informacje, a dziennikarz tylko uczestniczy w rozprawie. Powyższe uwagi znajdą zastosowanie, także w przypadku, gdy dziennikarz nie utrwala obrazu lub dźwięku a jedynie przytacza wypowiedzi, które padły podczas rozprawy. Jest to oczywiście dozwolone w świetle zasady jawności postępowania, za wyjątkiem sytuacji, gdy sąd takąjawność wyłączy ${ }^{30}$. Także w tym przypadku, wydaje się, że komentowany tu obowiązek nie będzie się aktualizować.

Jeszcze inny problem dotyczy relacji z konferencji prasowych. Zdaniem E. Nowińskiej w takim przypadku nie można żądać autoryzacji ${ }^{31}$, argumentując, że skoro osoby organizujące lub uczestniczące w takiej konferencji same zapraszają dziennikarzy, to decydują się także na publikację wypowiedzi. Trudno jednak z takim poglądem się zgodzić. Bo choć oczywiście można założyć, że osoby występujące na konferencji prasowej zakładają, że będą cytowane, ale przecież w tym przypadku może dojść do zamierzonej lub niezamierzonej manipulacji tekstem ${ }^{32}$, a po drugie wszystkie przesłanki z art. 14 ust. 2 pr.pr. są spełnione. Natomiast podzielić trzeba pogląd, iż autoryzacja dotyczy także osób, które anonimowo udzieliły wypowiedzi ${ }^{33}$. Również podzielić należy pogląd tej autorki, że wszelkie przekazy na żywo nie wymagają z powodów oczywistych autoryzacji.

W aktualnym stanie prawnym, dziennikarz nie ma prawnego obowiązku informowania o możliwości żądania autoryzacji, choć należy zgodzić się z tymi autorami, którzy stoją na stanowisku, że taki obowiązek można wywodzić z norm etycznych ${ }^{34}$. Zgłoszenie żądania może nastąpić w dowolnej formie ${ }^{35}$ i w dowolnym momencie, aż do chwili opublikowania takiego przekazu, tzn. przed, w trakcie oraz po udzieleniu wypowiedzi ${ }^{36}$. Natomiast w aktualnym stanie prawnym nie przewidziano, w jakiej formie (ustnej, pisemnej) należy tego obowiązku dopełnić. Należałoby sugerować oczywiście formę pisemną, chociażby ze względu na walor dowodowy. Natomiast w przypadku utrwalonych wypowiedzi pojawiają się trudności dowodowe z wykazaniem, że rzeczywiście osoba udzielająca wypowiedzi autoryzowała swoją wypowiedź. Oczywiście wiąże się to z faktem, iż na nośniku dźwięku lub obrazu nie można złożyć podpisu, co mogłoby mieć walor dowodowy. Wydaje się, że możliwym - choć zapewne nie idealnym rozwiązaniem - byłoby wykonanie kopii zapisu dla osoby zain-

\footnotetext{
${ }^{28}$ Ibidem, s. 178.

${ }^{29}$ Natomiast gdyby odpowiedzieć odmiennie na powyższe pytanie, należałoby rozstrzygnąć jeszcze inne zagadnienie, a mianowicie kto takim uprawnieniem dysponuje, czy każda osoba udzielająca informacji (np. świadek, pokrzywdzony, członek składu orzekającego, prokurator, obrońca itp.), czy sąd.

${ }^{30}$ E. Nowińska, M. du Vall, Sprawozdawczość sqdowa, w: Prawo mediów, red. J. Barta, R. Markiewicz, A. Matlak, Warszawa 2005, s. 276-279.

${ }^{31}$ E. Nowińska, op. cit., s. 124.

${ }^{32}$ O sposobach manipulacji wypowiedziami w takim przypadku patrz szerzej J. Sobczak, Prawo, op. cit., s. 559.

${ }^{33}$ M. Zaremba, op. cit., s. 112.

${ }^{34}$ Zob. postanowienie Sądu Najwyższego z dnia 30 sierpnia 2001 r., V KKN 118/99, OSNKW 2001, nr 11-12, cyt. za E. Ferenc-Szydełko, Prawo prasowe. Komentarz, Warszawa 2008, s. 124; podobnie J. Sobczak, Prawo prasowe, op. cit., s. 545.

${ }^{35}$ E. Nowińska, op. cit., s. 120. Zdaniem Autorki możliwe jest zgłoszenie takiego żądania ustnie bezpośrednio dziennikarzowi, telefonicznie, mailowo, faksem, choć forma pisemna może mieć istotny walor dowodowy.

${ }^{36}$ J. Taczkowska, Autoryzacja, op. cit., s. 61.
} 
teresowanej i uzyskanie od niej stosownego oświadczenia. Problematyczne jest też kto powinien ponieść ewentualne koszty autoryzacji (np. koszt dostępu do wypowiedzi). Zdaniem E. Nowińskiej koszty te powinien ponieść żądający autoryzacji ${ }^{37}$. Jeszcze inną kwestią jest odpowiedź na pytanie, jak powinien zachować się dziennikarz, który przekazał wypowiedź do autoryzacji, a osoba uprawniona nie zajmuje żadnego stanowiska. Nie ma wątpliwości, że aktualny stan prawny trybu realizacji tych uprawnień nie precyzuje. Zatem nie ma określonych normatywnie np. terminów przekazania wypowiedzi do autoryzacji, ani też jakim ,czasem" dysponuje osoba uprawniona. W ocenie E. Nowińskiej należy przyjąć, że brak reakcji w takim przypadku oznacza wyrażenie zgody ${ }^{38}$. Przeciwny pogląd prezentuje J. Sobczak, wedle którego przeciaganie terminu jej udzielenia nie upoważnia dziennikarza do publikowania wypowiedzi bez autoryzacji i nie zdejmuje z niego odpowiedzialności za taka publikację ${ }^{39}$. Podzielić należy ten ostatni pogląd i to nawet w przypadku, gdy dziennikarz przekazując tekst do autoryzacji, poinformuje, iż autoryzacji należy dokonać w określonym terminie. Natomiast jeżeli zostanie zawarta umowa (dziennikarz umówi się z interlokutorem), której treścią będzie klauzula, że brak stanowiska do pewnego terminu stanowi zgodę, wydaje się, że należy przyjąć, iż w takim przypadku możliwa będzie publikacja wypowiedzi bez narażania się na odpowiedzialność prawną, o której mowa w art. 49 pr.pr. Zgodzić trzeba się także z twierdzeniem E. Nowińskiej, iż możliwość ingerencji osoby uprawnionej w treść udzielonej wypowiedzi jest nieograniczona ${ }^{40}$. Wydaje się zatem, że uprawnienie do autoryzowania wypowiedzi nie sprowadza się jedynie do zaakceptowania przedstawionej wypowiedzi, ale też do jej korekty, precyzowania ${ }^{41}$.

Wątpliwości dotyczą także kwestii czy można zrzec się autoryzacji. Zdaniem niektórych autorów jest to niemożliwe, choć można umownie zobowiązać się, że nie skorzysta się z tego uprawnienia $^{42}$. Takie stanowisko wydaje się jednak niezrozumiałe. Nie bardzo bowiem wiadomo, jak wedle tego stanowiska, miałaby przedstawiać się różnica pomiędzy zrzeczeniem się a zobowiązaniem do niewykonywania tego uprawnienia. Stąd też należy się opowiedzieć raczej za stanowiskiem, iż możliwe jest zrzeczenie się takiego uprawnienia ${ }^{43}$. W takim przypadku osoba dysponująca takim prawem, informuje dziennikarza, że nie będzie korzystać $\mathrm{z}$ tego uprawnienia. Takie zrzeczenie można jednak odwołać i zażądać autoryzacji, tylko jednak do momentu publikacji.

Zgodnie z art. 14 ust. 2 ustawy autoryzacja dotyczy wyłącznie dosłownie cytowanych wypowiedzi. Obowiązek autoryzacji nie będzie się zatem aktualizował, jeżeli wypowiedź zostanie przedstawiona w mowie zależnej, a nie w formie cytatu ${ }^{44}$. Natomiast pewne wątpliwości mogą zrodzić się jeżeli chodzi o treści przygotowane przez samego dziennikarza, które zawierają wypowiedzi osoby uprawnionej do żądania autoryzacji, np. o pytania zadawane interlokutorowi. Może się bowiem zdarzyć, że do autoryzacji przekazane zostanie jedynie wypowiedź rozmówcy bez pytań, albo nawet z pytaniami, które zostaną później zmienione. To oczywiście może zmienić kontekst wypowiedzi. Zdaniem A. Karpowicza autoryzacja do-

${ }^{37}$ E. Nowińska, op. cit., s. 122

${ }^{38}$ Ibidem.

${ }^{39}$ J. Sobczak, Prawo, op. cit., s.562

${ }^{40}$ E. Nowińska, op. cit., s. 120.

${ }^{41}$ J. Sobczak, Prawo, op. cit., s. 540.

${ }^{42}$ M. Zaremba, op. cit., s. 111.

43 J. Sobczak, Prawo, op. cit., s. 559 oraz idem, Ustawa prawo prasowe. Komentarz, Warszawa 1999, s. 237.

${ }^{44}$ E. Nowińska, op. cit., s. 120. 
tyczy tylko samej wypowiedzi, nie zaś tekstu wytworzonego przez dziennikarza ${ }^{45}$. Zdaniem E. Nowińskiej obowiązek udostępnienia pytań, to raczej obowiązek natury deontologicznej niż prawnej ${ }^{46}$. Natomiast w ocenie B. Michalskiego udzielający wypowiedzi powinien znać takie pytania, które już później nie mogą być zmieniane ${ }^{47}$. W pełni podzielić należy stanowisko J. Sobczaka, iż jako czyn sprzeczny z etyka dziennikarska należy uznać przesłanie rozmówcy do autoryzacji tekstu bez dziennikarskich pytań, a następnie zastapienie w publikacji tekstu pytań, które rzeczywiście zostały zadane innymi - tak aby osiagnać zamierzony cel, a jest nim najczęściej ośmieszenie rozmówcy ${ }^{48}$. Oczywiście można założyć, że w takim przypadku możliwe będzie wdrożenie odpowiedzialności prawnej dziennikarza, tyle że - wydaje się - na innej podstawie prawnej, a mianowicie w oparciu o przepisy dotyczące ochrony dóbr osobistych.

Kolejną przesłanką ustawowa, jest uprzedni brak publikowania takiej wypowiedzi. Oznacza to, że obowiązek autoryzacji nie powstanie np. w przypadku przedruku ${ }^{49}$. Zdaniem E. Nowińskiej pojęcie publikacji w tym przypadku należy rozumieć raczej jako publiczne udostęnienie (wygłoszenie) ${ }^{50}$, w znaczeniu zbliżonym do pojęcia użytego w art. 25 ust. 1 pkt 4 (a więc mowy wygłoszone na publicznych zebraniach i rozprawach), a nie w kontekście definicji ustawowej terminu ,utwór opublikowany” zamieszczonej w art. 6 ust. 1 pkt 1 ustawy o prawie autorskim i prawach pokrewnych ${ }^{51}$.

Wspomnieć tu trzeba o jeszcze innej, odrębnej instytucji, a mianowicie o przewidzianym w art. 14 ust. 1 pr.pr. rozwiązaniu, zgodnie z którym publikowanie lub rozpowszechnianie $\mathrm{w}$ inny sposób informacji utrwalonych za pomocą zapisów fonicznych i wizualnych, wymaga zgody osób udzielających informacji ${ }^{52}$. Przepis art. 14 ust. 1 określa przesłanki publikowania lub rozpowszechniania informacji w formie zapisu fonicznego (dźwięk) i wizualnego (obraz), zawierające wypowiedzi osoby (informatora). Zauważa się, że powyższe rozwiązanie nie będzie dotyczyć wypowiedzi relacjonowanych na żywo. Wydaje się, że twierdzenie, iż reguły określone w art. 14 ust. 1 pr.pr. dotyczą tylko tych utrwaleń, które zawierają informacje, a nie już opinie, jest zbyt wąskie. Wprawdzie do takiego wniosku skłaniałby wynik wykładni gramatycznej, ale z kolei zastosowanie wykładni celowościowej nakazuje przyjąć, że ograniczenie instytucji z art. 14 ust. 1 tylko do informacji (pomijając opinie), byłoby nieuzasadnione. Natomiast w tym przypadku nie ma znaczenia, że zapis był wcześniej upubliczniony. Rozwiązanie to nie dotyczy natomiast utrwalenia jedynie wizerunku osoby, która nie udziela in-

45 A. Karpowicz, Prawo autorskie i prasowe dla dziennikarzy, Warszawa 1996, s. 108; zob. także Prawo mediów, red. J. Sieńczyło-Chlabicz, Warszawa 2013, s. 159; J. Taczkowska, op. cit., s. 66.

${ }^{46}$ E. Nowińska, op. cit., s. 120.

${ }^{47}$ B. Michalski, Podstawowe problemy prawa prasowego, Warszawa 1998, s. 45. Autor takie stanowisko wywodzi z konstrukcji prawa autorskiego, stojąc na stanowisku, iż w takich przypadkach mamy do czynienia $\mathrm{z}$ utworem wspólnym. Trzeba jednak zaznaczyć, że przecież nie każda wypowiedź będzie spełniać przesłanki określone w art. 1 ustawy z dnia 4 lutego 1994 r. o prawie autorskim i prawach pokrewnych (t.j. Dz. U. 2006, Nr 90, poz. 631 z późn. zm.). Patrz szerzej System Praw Prywatnego, t. 13: Prawo autorskie, red. J. Barta, R. Markiewicz, Warszawa s. $17-19$.

48 J. Sobczak, Prawo, op. cit., s. 557.

${ }^{49}$ E. Ferenc-Szydełko, op. cit., s. 119.

${ }^{50}$ E. Nowińska, op. cit., s. 124.

${ }^{51}$ Przypomnijmy, że zgodnie z tym przepisem $W$ rozumieniu ustawy: utworem opublikowanym jest utwór, który za zezwoleniem twórcy zostat zwielokrotniony i którego egzemplarze zostały udostęnione publicznie. Zdaniem J. Sobczaka ta definicja będzie decydująca. J. Sobczak, Prawo, op. cit., s. 561-562.

${ }^{52}$ Także w tym przypadku TK w Wyroku z dnia 29 września 2008 r. (sygn. akt SK 52/05) orzekł, iż jest on zgodny z art. 14 i 54 ust. 1 Konstytucji. Stąd też należy pamiętać, że w przypadku naruszenia tego obowiązku grozić będzie sankcja przewidziana w art. 49 pr.pr. Patrz też J. Sobczak, Prawo prasowe, s. 539. 
formacji, ale w takich przypadkach ochrona może wynikać z art. 81 pr.aut. W doktrynie podnosi się, że pojęcie publikowania w tym przypadku, rozumie się jako upublicznienie informacji $w$ formie materiał u prasowego ${ }^{53}$, a rozpowszechnianie $w$ inny sposób to upublicznienie w innej postaci (np. sms, MMS, serwisy społecznościowe, VoD) $)^{54}$. Zważywszy na rozwiązania normatywne, należy być konsekwentnym i przyjąć, że pojęcie publikowania będzie w tym przypadku identyczne z tym o jakim mowa w art. 14 ust. 2 pr.pr. Wówczas rozpowszechnianie w inny sposób obejmowałoby takie formy jak chociażby wyżej wspomniane sms, MMS, serwisy społecznościowe, pocztę elektroniczną.

Warto porównać obie instytucje, wskazując na podobieństwa i różnice w ust. 1 i 2 art. 14. Te pierwsze to przede wszystkim możliwość współdecydowania w obu przypadkach o rozpowszechnianiu informacji, konieczność uzyskania zgody od każdego z informatorów (tylko osób fizycznych, a nie prawnych), bez względu na ich status społeczny (np. czy jest to osoba publiczna $)^{55}$. Natomiast pośród różnic wskazuje się, iż autoryzacja jest prawem podmiotowym $^{56}$, z możliwością dysponowania (np. zrzeczenia się), natomiast zgoda, o której mowa w ust. 1 tego przepisu nie może być traktowana jako prawo podmiotowe, a jedynie warunek dopuszczający publikację ${ }^{57}$. Wydaje się jednak, że takie twierdzenie jest zbyt dużym uproszczeniem. Wydaje się bowiem, że zarówno autoryzacja ${ }^{58}$, jak i zgoda z art. 14 ust. 1 to elementy składające się na złożoną sytuację prawną zwaną prawem podmiotowym. Zatem zarówno autoryzację, jak i ową zgodę, o której mowa w art. 14 ust. 1 pr.pr. można traktować jako uprawnienie, będące elementem prawa podmiotowego łączącego osobę uprawnioną z podmiotem zobowiązanym do uzyskania zgody. Zdaniem E. Ferenc-Szydełko pojęcie zgody w art. 14 ust. 1 powinno być traktowane szeroko, zgodnie z dyrektywami art. 60 k.c. Zgodnie z tym przepisem oświadczenie woli może być wyrażone przez każde zachowanie się tej osoby, które ujawnia jej wolę w sposób dostateczny. Jeśli np. osoba świadomie udziela wypowiedzi do mikrofonu z logo radiostacji, podstawionego przez dziennikarza, to należy przyjać, że jej zachowanie ujawnia wolę publikacji tej wypowiedzi ${ }^{59}$. Zgodzić trzeba się także z tezą, że może to być czynność nieodpłatna lub odpłatna. Żądanie zapłaty za taką zgodę jest dopuszczalne. Aczkolwiek jeżeli zgoda dotyczyłaby osoby, która zobowiązana jest do udzielenia informacji publicznej, to podzielić należy stanowisko, iż w takim przypadku można rozważać zastosowanie konstrukcji nadużycia prawa podmiotowego ${ }^{60}$. Zdaniem B. Kosmusa i G. Kuczyńskiego

\footnotetext{
53 Prawo prasowe. Komentarz, red. B. Kosmus, G. Kuczyński, Warszawa 2011, s. 239.

${ }^{54}$ Ibidem.

55 Ibidem.

${ }^{56}$ Wyjaśnijmy tu, że prawo podmiotowe to kategoria nadrzędna w stosunku do uprawnień, nadrzędna w tym sensie, że prawo podmiotowe obejmuje jedno lub więcej uprawnień, zwiqzanych ze sobq funkcjonalnie i stanowiacych element danego typu stosunku prawnego. (A. Wolter, Prawo cywilne, zarys części ogólnej, Warszawa 1963, s. 95). Wedle Z. Radwańskiego jest to pewna złożona sytuacja prawna wyznaczona podmiotom przez obowiazujace normy i chroniaca prawnie uznane interesy tych podmiotów. Na sytuację tę sktadaja się wolne - w aspekcie normatywnym - zachowania psychofizyczne lub konwencjonalne podmiotu uprawnionego, z którymi sprzężone sq zawsze obowiqzki innego podmiotu lub innych podmiotów, przy czy z reguly (to znaczy, gdy norma prawna tego nie wyłacza) uprawnionemu przysługuje również kompetencja do żqdania, by organ państwa dysponujacy przymusem doprowadzil do zrealizowania sprzężonych z prawem podmiotowym obowiąków. (Z. Radwański, Prawo cywilne - część ogólna, Warszawa 1993, s. 71).

${ }^{57}$ B. Kosmus, G. Kuczyński (red.), op. cit., s. 239.

${ }^{58}$ Choć autoryzację można rozumieć dwojako, a mianowicie jako samo oświadczenie woli podmiotu uprawniającego wyrażającego zgodę na publikację dosłownie cytowanej wypowiedzi, jak i szerzej jako sytuację dwóch podmiotów prawa, a mianowicie dziennikarza i jego interlokutora.

${ }^{59}$ E. Ferenc-Szydełko, op. cit., s. 118; podobnie E. Nowińska, op. cit., s. 124.

${ }^{60}$ Tak art. 5 k.c. Por. B. Kosmus, G. Kuczyński (red.), op. cit., s. 241.
} 
adresatami normy z art. 14 ust. 1 są nie tylko przedstawiciele prasy, ale także każdy kto posiada zapisy foniczne lub wizualne ${ }^{61}$. Wydaje się jednak, że jest to zbyt szerokie rozumienie tego przepisu. Należy jednak pamiętać o kontekście normatywnym tej regulacji i umieszczeniu tej normy w prawie prasowym, w rozdziale 2 tego aktu normatywnego poświęconym prawom i obowiązkom dziennikarzy. Zgodzić natomiast należy się z tezą, iż nie ma konieczności argumentowania, dlaczego korzysta się z tej informacji. Także w tym przypadku zgoda taka musi istnieć najpóźniej w dniu publikacji. Również tu nie przewidziano jakiegoś szczególnego trybu, a więc np. terminu, w którym można skorzystać z tego uprawnienia i jakie są skutki milczenia osoby uprawnionej. Inicjatywa - a więc inaczej niż w przypadku autoryzacji - należy do osoby dysponującej ,zapisem"62 . Nie będzie naruszeniem tej normy, przekazanie treści wypowiedzi w formie relacji (mowy zależnej) ${ }^{63}$. Natomiast jako naruszenie powyższej normy wskazuje się przypadki nagrania tzw. „ukrytą kamerą"64. Pojawiają się także wątpliwości, czy obie instytucje są od siebie niezależne, tzn. czy skorzystanie np. z instytucji autoryzacji powoduje, że uzyskanie zgody z ust. 1 tego przepisu jest bezprzedmiotowe. Zdaniem E. Nowińskiej te instytucje muszą być traktowane jako samodzielne byty ${ }^{65}$. Stąd należałoby zabiegać niejako o „podwójną” zgodę. Podzielając co do zasady ten pogląd, należy jednak przyjąć, że autoryzowanie wypowiedzi, stanowić może jednocześnie w sposób dorozumiany wyrażenie zgody z art. 14 ust. 1 pr.pr.

Nie mniejsze wattpliwości dotyczą stosowania tej instytucji w mediach elektronicznych i tzw. nowych mediach. Po pierwsze należy zauważyć, że zważywszy na treść art. 3 ustawy z dnia 29 grudnia 1992 r. o radiofonii i telewizji ${ }^{66}$, przepisy dotyczące autoryzacji, jak i instytucji opisanej w art. 14 ust. 1 pr.pr., stosuje się w przypadku radiofonii i telewizji ${ }^{67}$, choć korzystanie z tej konstrukcji odnośnie mediów elektronicznych budziło od początku wiele wątpliwości. Pojawiały się głosy ze strony praktyki, iż specyfika pracy dziennikarzy radiowych i telewizyjnych - tzn. rejestrowanie wypowiedzi i przytaczanie ich fragmentów w całości, ale zwłaszcza szybkość „cyklu produkcyjnego” w takich redakcjach, uprawnia do rezygnacji z konieczności uzyskania autoryzacji ${ }^{6}$. Krytycznie w stosunku do aktualnego w tym zakresie stanu prawnego, wypowiada się część przedstawicieli doktryny, jak i judykatury. Podnosi się, iż archaiczne przepisy prawa prasowego, nie pasuja od lat do rzeczywistości wolnego, otwartego, pluralistycznego spoteczeństwa także dlatego, że ignoruja kompletnie rewolucję technologiczna, która gruntownie zmieniła sposób pozyskiwania i rozpowszechniania informacji poprzez publiczne i prywatne stacje radiowe oraz telewizyjne. Autoryzacja obowiqzuje dziennikarzy powiqzanych jakaś forma umowy z jakimkolwiek środkiem społecznego przekazu. W praktyce jednak, z natury rzeczy, dotyczy ona dziennikarzy prasowych oraz mediów internetowych ${ }^{69}$. Argumentuje się, że specyfika mediów elektronicznych polega na

\footnotetext{
${ }^{61}$ Ibidem, s. 239.

${ }^{62}$ Ibidem, s. 240.

${ }^{63}$ Ibidem, s. 241.

${ }^{64}$ E. Ferenc-Szydełko, op. cit., s. 118, a także B. Kosmus, G. Kuczyński (red.), op. cit., s. 241. Zgodzić się należy z Autorami, iż podobnie należy traktować przypadki ukrytej kamery „na żywo”. Bo choć nie mamy tu do czynienia $\mathrm{z}$ utrwaleniem, to jednak reguły wnioskowania a maiori ad minus pozwalają dojść do takich konkluzji.

${ }^{65}$ E. Nowińska, op. cit., s. 124.

${ }^{66}$ Ustawa z dnia 29 grudnia 1992 r. o radiofonii i telewizji, t.j. Dz. U. 2011, Nr 43, poz. 226 z późn. zm.

${ }^{67}$ Zob. J. Sobczak, Radiofonia i telewizji. Komentarz do ustawy, Kraków 2001, s. 74; J. Taczkowska, op. cit., s. 62.

${ }^{68}$ J. Taczkowska, Autoryzacja, s. 158; J. Skrzypczak, Polityka medialna w okresie konwersji cyfrowej radiofonii i telewizji, Poznań 2011, s. 229 i n.

${ }^{69}$ Tak A. Rzepliński, op. cit., s. 101.
} 
tym, że dziennikarze albo nadają materiały na żywo, albo nagrywają wypowiedź kilkuminutową, a następnie wybierają do materiału prasowego jedynie fragment wypowiedzi. Rozmówca powinien wiedzieć o takiej procedurze postępowania i mówić zwięźle (co rzadko się zdarza), albo zrezygnować z rozmowy ${ }^{70}$. W aktualnym stanie prawnym, postulowanego przez wielu dziennikarzy wyjątku w stosowaniu autoryzacji wobec mediów elektronicznych nie przewidziano, zatem opisany sposób postępowania jest nieprawidłowy i może wiązać się z odpowiedzialnością przewidzianą w art. 49 pr.pr. ${ }^{71}$ Tym bardziej, że manipulacja wypowiedzią w przypadku mediów elektronicznych jest bardzo łatwa do wykonania. Zdaniem E. Nowińskiej w obecnym stanie prawnym autoryzacja dotyczy wszystkich dziennikarzy, niezależnie od tego jaki rodzaj mediów reprezentuja, tzn. czy są to przedstawiciele gazety, radia czy telewizji ${ }^{72}$. Choć należy podzielić co do zasady powyższy pogląd, to jednak trzeba od razu dodać, że obecnie pojawiają się ogromne wątpliwości w kwestii, kogo można zaliczyć do kategorii prasy ${ }^{73}$, jak

${ }^{70}$ E. Nowińska, Wolność wypowiedzi prasowej, s. 121.

${ }^{71}$ Przypomnijmy, że zgodnie z tym przepisem kto narusza m.in. postanowienia art. 14 pr.pr. podlega grzywnie albo karze ograniczenia wolności.

${ }^{72}$ E. Nowińska, op. cit., s. 119.

${ }^{73}$ Przypomnijmy tu, że zgodnie z definicją ustawową pojęcie ,„prasa” oznacza publikacje periodyczne, które nie tworzq zamkniętej, jednorodnej całości, ukazujace się nie rzadziej niż raz do roku, opatrzone stałym tytułem albo nazwa, numerem bieżacym i data, a w szczególności: dzienniki i czasopisma, serwisy agencyjne, stałe przekazy teleksowe, biuletyny, programy radiowe i telewizyjne oraz kroniki filmowe; prasq sq także wszelkie istniejace i powstajace $w$ wyniku postęu technicznego środki masowego przekazywania, w tym także rozgłośnie oraz tele- $i$ radiowęzły zakładowe, upowszechniajace publikacje periodyczne za pomoca druku, wizji, fonii lub innej techniki rozpowszechniania. (Tak art. 7 ust. 2 pkt 1 pr.pr.). W doktrynie na tle definicji ustawowej wskazuje się trzy możliwe sposoby pojmowania pojęcia ,prasa”, a mianowicie a) prasa w znaczeniu przedmiotowym (będaca przekazem o określonych cechach), b) prasa $w$ znaczeniu instytucjonalnym (utożsamiana ze środkami masowego przekazu) oraz c) prasa w znaczeniu podmiotowym (oznaczajaca zespoly ludzi i poszczególne osoby zajmujace się działalnościa dziennikarska. (Tak E. Czarny-Drożdżejko, Dziennikarskie dochodzenie prawdy a przestęstwo zniesławienia $w$ środkach masowego przekazywania, Kraków 2005, s. 195). Jak z powyższego wynika, niezbędnymi przesłankami konstytuującymi pojęcie prasy jest periodyczność, otwartość i różnorodność treści, określona częstotliwość ukazywania się (nie mniej niż raz do roku) oraz stały tytuł, numer bieżący i data. (I. Dobosz, Prawo prasowe. Podręcznik, Warszawa 2006, s. 75). Dodać od razu jednak trzeba, że nie wszystkie powyższe przesłanki traktuje się jednakowo. Twierdzi się, że np. wymóg periodyczności ma znaczenie kluczowe, a inne np. numer bieżący i datę traktuje się jako kryteria pomocnicze, których brak nie powoduje automatycznie utraty statusu prasy. (Tak M. Zaremba, Prawo prasowe. Ujęcie praktyczne, Warszawa 2007, s. 27. Por. J. Skrzypczak, Polityka medialna w okresie konwersji cyfrowej radiofonii i telewizji, Poznań 2011, s. 199 i n.). Jednak największe spory dotyczą kategoryzowania w świetle powyższej definicji legalnej przekazów internetowych. Podzielić należy pogląd, że dzienniki i czasopisma z tego powodu, że ukazują się w internecie, nie tracą cech prasy. Dotyczy to zarówno sytuacji, gdy wersja internetowa jest niemal identyczna z ,wydaniem papierowym”, jak również, gdy funkcjonuje tylko w formie elektronicznej w sieci, ukazując się periodycznie. (J. Sobczak, Prawo..., teza 3 do art. 7, s. 318-319; J. Barta, Problem goni problem, „Rzeczpospolita” 1998, nr 4, s. 15; podobnie E. Nowińska, M. du Vall, Komentarz do ustawy o zwalczaniu nieuczciwej konkurencji, Warszawa 2001, s. 184; E. Nowińska, Nieuczciwa reklama w Internecie, w: Internet-problemy prawne, red. R. Skubisz, Lublin 1998, s. 51). Powyższe stanowisko koresponduje z poglądami judykatury. Wydaje się, że linia orzecznicza jest także obecnie ugruntowana, choć w przeszłości pojawiały się w tej materii różne stanowiska. I tak w postanowieniu SN z dnia 26 lipca 2007 r. zauważono, że osoba rozpowszechniająca bez rejestracji w właściwym sqdzie okręgowym dziennik bądź czasopismo za pośrednictwem Internetu zarówno wówczas, gdy przekaz taki towarzyszy przekazowi utrwalonemu na papierze, stanowiac innq elektroniczna jego postać, jak i wówczas gdy istnieje tylko w formie elektronicznej w Internecie, wyczerpuje znamiona przestępstwa z art. 45 ustawy-Prawo prasowe. Zob. Postanowienie SN z dnia 26 lipca 2007 r. (sygn. akt IV KK 174/2007), „Orzecznictwo Sądu Najwyższego w Sprawach Karnych”2007, poz. 1737. Zob. także glosę aprobującą J. Taczkowskiej, „OSP” 2008, nr 6, s. 414 oraz krytyczną E. Czarny-Drożdżejko, Glosa, s. 84, a także W. Górowskiego, „PiP” 2008, nr 6, s. 127. Przywołać należy tu Postanowienie SN z 7 maja 2008 r. (sygn. akt III KK 234/87), opublik. w „Biul. PK” 2008, nr 10, s. 33, gdzie wyrażono pogląd (tak tezy 2 i 4), iż Internetowy przekaz o charakterze periodycznym, spetniajacy wymogi przewidziane przez ustawodawce $w$ treści art. 7 ust. 2 pkt 1 [...] pr.pr. niewatpliwie jest prasq. [...] Środkami masowego komunikowania będa wszystkie środki, 
i dziennikarza ${ }^{74}$. A to przecież oba terminy będą rzutować na zakres podmiotowy omawianych tu instytucji.

Jak już wyżej sygnalizowano, szczególne wattpliwości dotyczą stosowania tej instytucji w środowisku mediów cyfrowych ${ }^{75}$. Wydaje się, że odnośnie linearnych cyfrowych przekazów naziemnych, satelitarnych, kablowych i mobilnych instytucja pozostaje w pełni aktualna. W tych wszystkich przypadkach znajdą zastosowanie wszystkie reguły, które odnoszą się do przekazów radiofonicznych lub telewizyjnych. Natomiast wątpliwości rodzą się w przypadku przekazów internetowych, w szczególności ze względu na różnorodność występujących w sieci zjawisk. I tak odnośnie medialnych (audio i audiowizualnych) usług linearnych ${ }^{76}$ dostępnych w internecie, wydaje się, że powyższe zasady znajdą pełne zastosowanie. Podkreślić bowiem należy, że platforma internetowa jest tylko jedną z form dystrybucji treści. Niemniej w doktrynie spotkać można pogląd, że w materiałach prasowych zamieszczanych w internecie mamy najczęściej do czynienia z przeredagowaniem istniejących wcześniej już materiałów prasowych. $Z$ tej przyczyny, twierdzą niektórzy autorzy, nie ma obowiązku dokonywania autoryzacji przekazów internetowych, bowiem temu obowiązkowi podlegają tylko wypowiedzi

których działanie sprowadza się do masowego przekazywania rozmaitych treści. Czyli do środków tych wypadnie zaliczyć nie tylko prasę drukowana, przekaz radiowy i telewizyjnych, lecz także ksiażke, plakat, film oraz przekaz za pomocq Internetu [...]. Wymienić w tym nurcie należy stanowisko wyrażone w Wyroku Sądu Rejonowego w Stupsku $z$ dnia 16 grudnia 2008 r. (sygn. akt II K 367/2008), opublik. „LexPolonica” nr 2077260. Na uwagę zasługuje także Postanowienie WSA w Warszawie z dnia 30 października 2008 r., sygn. akt II S.A./WA 1885/07, opublik. LEX nr 521930), gdzie w t. 2 wyrażono następujący pogląd: Periodyki internetowe, by mogty być uznane za wydawnictwa prasowe, wcale nie muszq mieć postaci typowych gazet elektronicznych, których wydawcami sq tylko wielkie koncerny prasowe, firmujace jedynie znane tytulu publikatorów w systemie on line. O tym czy publikacja internetowa ma charakter prasowy decydować powinien cel, jakiemu ma stużyć. Skoro rola i zadaniem prasy jest rozpowszechnianie informacji, to periodyczność przekazu, czyli cyklicznego informowania opinii publicznej o określonych faktach społecznych, ekonomicznych, gospodarczych, politycznych, oświatowych, kulturalnych z zakresu muzyki, filmu i sztuki, etc. pod oznaczonym tytułem, nazwa, adresem czy nawet linkiem, wskazywać będzie na cel, jaki realizuje redakcja, wydawca czy autor danej publikacji elektronicznej, na stworzonej specjalnie w tym celu stronie internetowej. Por. także orzeczenie SN z 15.12.2010 r. (sygn. akt III K 250/10). Komunikat na ten temat został zamieszczony na stronie http://www.sn.pl/aktual/index.html. W niektórych przypadkach sądy odmawiały rejestracji dzienników i czasopism internetowych (np. Postanowienie SA w Rzeszowie z 25 maja 2005 r. I ACa 277/05; Postanowienie SO w Krośnie z 17 marca 2005 r., I Ns.Rej.Pr. 3/05. W innych stanowisko było odmienne (patrz Postanowienie SO w Poznaniu z 30 czerwca 2005 r., I Ns.Rej.Pr 75/05; Postanowienie SO w Warszawie z 17 lutego 2005 r., VII Ns.Rej.Pr. 69/05; E. Nowińska, Prasa drukowana, w: Prawo mediów, red. J. Barta, R. Markiewicz, A. Matlak, Warszawa 2008 , s. 96. Podobnie S. Jankiewicz, Prowadzenie reklamy w Internecie, „Radca Prawny” 2001, nr 2, s. 40. Patrz szerzej J. Skrzypczak, op. cit., s. 191-210. Choć od razu warto zaznaczyć, że nie ma obowiązku rejestracji strony internetowej. Obowiązek taki, w świetle art. 45 Prawa prasowego, dotyczyć będzie wyłącznie prasy ukazującej się w internecie. Taki paradoksalny wniosek wynika z wyroku Trybunału Konstytucyjnego z dnia 14 grudnia 2011 r. Wyrok Trybunału Konstytucyjnego z dnia 14 grudnia 2011 r., syg. akt SK 42/09, opublik. OTK-A 2011/10/118. Jak widać bez najmniejszego problemu, przy minimalnych czy nawet żadnych nakładach finansowych, można zostać wydawcą prasy. A to problem nakładów finansowych był do niedawna główną barierą wejścia na rynek medialny.

${ }^{74}$ Natomiast za dziennikarza w świetle definicji zamieszczonej w prawie prasowym, będzie uważana osoba zajmująca się redagowaniem, tworzeniem lub przygotowywaniem materiałów prasowych, pozostająca w stosunku pracy z redakcją albo zajmująca się taką działalnością na rzecz i z upoważnienia redakcji. W świetle powyższej definicji ustawowej, można twierdzić, że dziennikarzem może być każdy, kto spełnia powyższe wymogi, a zatem każdy kto tak twierdzi. Wprawdzie jest tu stawiany wymóg działania na rzecz i z upoważnienia redakcji, ale jak wyżej wykazano, utworzenie redakcji np. prasy internetowej, jest niezwykle proste i tanie. Zatem może to uczynić niemal każdy, a w konsekwencji uzyskać status dziennikarza.

${ }^{75}$ Cyfryzacja mediów rozumiana jako określony proces metamorfozy radiofonii i telewizji, polegający na wdrażaniu emisji cyfrowych. na platformach naziemnych, kablowych i satelitarnych. Patrz szerzej J. Skrzypczak, op. cit., s. $27-41$.

${ }^{76}$ Także gazet ukazujących się w internecie. 
wcześniej niepublikowane ${ }^{77}$. Taki pogląd trzeba opatrzyć jednak komentarzem, iż wskazywana praktyka jest rzeczywiście dość częsta, jednak nie jest ona cechą dystynktywną komunikacji interentowej. W przypadku treści publikowanych poza siecią też przecież takie sytuacje mogą zaistnieć.

Zwraca się uwagę jeszcze na inny kontekst autoryzacji w internecie. Wskazuje się, że wszelkie treści pojawiające się na tej platformie można podzielić na dwie grupy, a mianowicie kontrolowane przez administratora serwisu i niekontrolowane przez nikogo. Argumentuje się, że w tym pierwszym przypadku następuje ,autoryzowanie” przez wydawcę internetowego. Wspomina się nawet o ciążącym na takim podmiocie obowiązku eliminacji treści szkodliwych $^{78}$. Wydaje się, że jest to jednak zupełnie inne zagadnienie, niezwiązane z instytucją autoryzacji. Istota tejże polega przecież na tym, że to podmiot, który udziela wypowiedzi, dysponuje takim prawem, a nie jakaś osoba trzecia ${ }^{79}$. Jak już wyżej sygnalizowano obie instytucje $\mathrm{z}$ art. 14 pr.pr. mają charakter praw osobistych.

W przypadku usług dostępnych na żądanie problem jest jeszcze bardziej skomplikowany. W art. 14 ust. 2 pr.pr. mowa jest o tym, iż obowiązek autoryzacyjny ciąży na dziennikarzu, który zamieszcza dosłownie cytowaną wypowiedź. Stąd też należy stwierdzić, że jeżeli materiał dostępny w systemie VoD ma charakter materiału prasowego ${ }^{80}$, to charakteryzowana instytucja zachowuje pełną stosowalność. Wydaje się, że także w przypadku instytucji opisanej w art. 14 ust. 1 pr.pr., obowiązek ten będzie aktualny. Podnieść tu trzeba jeszcze jedną kwestię. A mianowicie można przyjąć założenie, że komentowane tu instytucje dotyczyć będą tylko przypadków, o których mowa w ustawie o radiofonii i telewizji. A skoro tak to przypomnijmy, że zgodnie z art. la ustawy o radiofonii i telewizji ustawę tę stosuję się do tzw. dostawców usług medialnych. Z kolei w art. 4 tego aktu normatywnego wyjaśniono, że usługą medialną jest usługa w postaci programu, za którą odpowiedzialność redakcyjną ponosi jej dostawca i której podstawowym zadaniem jest dostarczenie przez sieci telekomunikacyjne ogółowi odbiorców audycji, w celach informacyjnych, rozrywkowych lub edukacyjnych. Jednocześnie w art. 2 ust. 2 zamieszczono szereg wyłączeń. I tak z punktu widzenia poruszanej tu problematyki, na szczególną uwagę zasługuje wykluczenie z zakresu stosowania tego aktu normatywnego programów radiowych rozpowszechnianych wyłącznie w systemach teleinformatycznych oraz audialnych usług na żądanie, jak również elektronicznych wersji dzienników i czasopism oraz prasy udostępnianej w systemie teleinformatycznym pod warunkiem że nie składają się w przeważającej części z audycji audiowizualnych. Stąd też należy przyjąć, że stwierdzenie, że instytucje określone w art. 14 ust. 1 i 2 będziemy stosować wyłącznie odnośnie form aktywności regulowanych ustawą o radiofonii i telewizji, nie może się obronić. Bo przecież trudno zaakceptować tezę, iż można domagać się autoryzacji w przypadku internetowych dzienników i czasopism, a nie treści pojawiających się w programach radiowych rozpowszechnianych wyłącznie w systemach teleinformatycznych oraz audialnych usługach medialnych na żądanie.

Jak widać opisywaną sytuację nazwać należy z pewnością jako kryzysową. Trudno przy tym założyć, że interwencja ustawodawcy rozwiąże całkowicie powyższe problemy, chociażby zważywszy na tempo pojawiania się nowych form aktywności internetowych.

\footnotetext{
77 J. Taczkowska, Kategorie wypowiedzi i ich ochrona, Warszawa-Poznań 2008, s. 249.

${ }^{78}$ Ibidem, s. 250. Na marginesie warto zwrócić uwagę na rodzące się w takich przypadkach wątpliwości, czy nie mamy do czynienia z niedopuszczalną cenzurą prewencyjną. Pamiętać bowiem należy, że w przywołanym przypadku weryfikacji wypowiedzi dokonuje inny podmiot niż ten, który jej udzielał.

${ }^{79}$ J. Skrzypczak, op. cit., s. 229 i n.

${ }^{80}$ Co do wątpliwości z definiowaniem pojęcia prasa i materiał prasowy patrz wyżej.
} 


\section{Authorization in the Use of New Media during a Period of Crisis in the Press Law System}

\section{Summary}

Assuming that a crisis infers the collapse of old values while the new ones to replace them have not developed yet, one can ponder whether we are witnessing a crisis of press law in Poland or not. Taking into consideration the gravity and scope of criticism of the current press law act and the repeated attempts to alter the existing legal status quo, it could be said that we are facing a permanent crisis in the press law system in Poland, and, consequently, of the whole media policy. The paper tries to verify this hypothesis on the example of one of the elements of the press law, namely that of authorization. 
